\title{
Antropologiczne implikacje wychowania do zrównoważonego rozwoju
}

Zjawisko wychowania jest stale związane $\mathrm{z}$ historią ludzkiego bytu. Człowiek ciągle podlega procesom wychowawczym i zarazem sam jest kimś, kto aktywnie uczestniczy w wychowaniu innych osób. Wychowanie różni się od tresury, która jest właściwa dla świata zwierząt. Wychowanie bowiem jest działaniem uwzględniającym świadomość i wolność osoby ludzkiej, które są podstawą osobowej godności człowieka. Tresura natomiast bazuje na determinacjach obecnych w związkach towarzyszących relacjom, jakie zachodzą między bodźcem a reakcją. W przypadku człowieka również możemy dostrzec pewne elementy determinacji, nie mają one jednak charakteru absolutnego. Człowiek może się sprzeciwić tym determinacjom, może nimi kierować.

\section{Cele wychowania}

Przyzwyczailiśmy się ograniczać zjawisko wychowania do zabiegów wychowawczych związanych z edukacją dzieci i młodzieży. Szkoła jest miejscem szczególnym, w którym edukacja i wychowanie są ze sobą związane i mają na celu kształtowanie postaw młodego pokolenia. Tymczasem zjawisko wychowania nie kończy się wraz z otrzymaniem dyplomu ukończenia szkoły. Człowiek dorosły również podlega procesom wychowawczym. Na jego postawę ma wpływ działanie mass mediów, wpływ środowiska, w którym przebywa, szkoły, kościoła, wpływ obowiązującego prawa. Szczególną rolę odgrywa kształt obowiązującego prawa i jego respektowanie. Prawo pełni bowiem w społeczeństwie funkcję wychowawczą, choć nie zawsze ustawodawca zdaje sobie z tego sprawę. Ostatnie lata ukazują w Polsce zmianę świadomości obywateli, w sprawach dotyczących wartości ludzkiego życia oraz sprawach związanych z ochroną środowiska naturalnego, w którym człowiek żyje. Zmiany te niewątpliwie związane są z respektowaniem obowiązującego prawa, prawo bowiem winno ukazywać ludziom prawdę o dobrach, które podlegają ludzkim wyborom. Niewątpliwie takim dobrem jest wartość środowiska. 
Jeśli chcielibyśmy w sposób możliwie prosty powiedzieć, czym jest wychowanie, co należy do jego istoty, to moglibyśmy powiedzieć, że jest ono kształtowaniem konkretnego człowieka we wszystkich dziedzinach jego życia. Kształtowanie to zmierza w kierunku doskonalenia działania człowieka oraz samego człowieka jako człowieka, czyli jako osobę ludzką. Działania związane z wychowaniem mają na celu umożliwienie osobie maksymalny rozwój własnych osobowych potencjalności. Jako istota wolna i świadoma, osoba ludzka swoimi aktami wolnego wyboru sama będzie w sposób aktywny uczestniczyć w procesie realizacji owych doskonałości. Wychowanie nie jest tresurą, lecz ma na celu takie przygotowanie wychowanka, aby mógł on sam, w sposób wolny podejmować ważne życiowo decyzje. Wychowanie realizuje się poprzez świadome przyzwyczajanie się do czynienia dobra. O. Jacek Woroniecki mówi nawet w tym kontekście o „nawykaniu do dobrego”. Na tym stopniu uogólnienia można również powiedzieć, że wychowanie jest pewnym procesem zachodzącym między naturą człowieka, a kulturą, którą człowiek zastaje w chwili swoich narodzin. Proces ten ma specyficzny charakter. Z jednej strony kultura wpływa na rozwój i dojrzewanie człowieka, $\mathrm{z}$ drugiej jednak strony sam człowiek, w miarę swego dojrzewania, tworzy i rozwija kulturę.

Podane wyżej określenia tego, czym jest wychowanie, stwarzają jednak niebezpieczeństwo interpretacji, w myśl której społeczeństwo i kultura byłyby jedynymi i decyduąacymi podmiotami procesu wychowania, a samo wychowanie byłoby dziełem społeczeństwa i dominowałyby w nim elementy manipulacji drugą osobą. Jednocześnie cele wychowania i wartości realizowane w tym procesie mogłyby być bądź wcześniej dokładnie wyznaczone przez odpowiednie czynniki społeczne - jest to typowa sytuacja manipulacji i w konsekwencji tresury - bądź też wartości te byłyby wypadkową panującej w społeczeństwie sytuacji moralnej. Nie ulega wątpliwości, że kultura w której żyjemy, zastane struktury społeczne, stan i system szkolnictwa, moda, obowiązujące prawo pozytywne, sytuacja polityczna, mass media, Kościół, mentalność panująca w domu rodzinnym są nosicielami wartości i uczestniczą w procesie wychowawczym. Działają one na każdą osobę ludzką, żyjącą w danej społeczności, zostawiając pewien ślad w sposobie myślenia i postawie poszczególnego członka społeczności. Winny one umożliwić osobie rozpoznanie dobra oraz jego realizację. Należy mocno podkreślać ich odpowiedzialność za każdego człowieka będącego w polu ich oddziaływania.

Wychowanie określiliśmy jako kształtowanie człowieka, jako proces doskonalenia się osoby ludzkiej. Struktury społeczne mogą sprzyjać osobie w tym procesie lub też mogą zakłócać rozwój, ku któremu osoba w swej istocie jest odniesiona. Nikt z pewnością nie będzie negować tego, iż zadaniem wszelkich instytucji społecznych jest wspomaganie osoby w jej dążeniu do prawidłowego rozwoju tkwiących w niej możliwości. Winny one stwarzać odpowiednie warunki tego rozwoju, a także chronić osobę przed wszelkimi pseudo - wartościami. 
Celem wychowania jest bowiem stworzenie takich warunków, w których osoba, rozpoznając pewne wartości będzie mogła świadomie rozwijać swe osobowe potencjalności, a jej rozwój staje się dobrem całego społeczeństwa. Kształt owych warunków musi być dostosowany do wieku wychowanka. Innych warunków domaga się wiek szkolny dziecka, a inne warunki potrzebne są w procesie wychowywania osób dorosłych, np. w zakresie kształtowania postawy odpowiedzialności za stan środowiska naturalnego.

Określiliśmy wychowanie jako kształtowanie, doskonalenie osoby ludzkiej, ona właśnie jest celem i podmiotem wychowania. Powstaje pytanie o kierunek tegoż doskonalenia. Wychowanie nie jest bowiem procesem przebiegającym w jakieś aksjologicznej próżni, nie jest również chaotycznym modelowaniem kogoś lub siebie samego. Wychowanie powinno przebiegać $\mathrm{w}$ atmosferze pewnego ładu, porządku, który trzeba odkryć. Porządek ten wyznaczony jest tym, kim człowiek jest w swej istocie oraz tym, jaką wartość ma to, co otacza człowieka oraz jak relacja zachodzi między człowiekiem, a otaczającą go rzeczywistością. Kształtowanie się, doskonalenie się jest procesem przebiegającym na płaszczyźnie moralnej. Ta płaszczyzna towarzyszy wszelkim relacjom człowieka wobec świata przyrody oraz wobec siebie samego. Wychowanie człowieka realizuje się tylko poprzez moralność, poprzez działania moralnie dobre. Kształcenie charakteru, intelektu, nabywanie wiedzy nieodłącznie związane jest właśnie z moralnością. W związku z tym wydaje się, iż ład, w którym powinien przebiegać proces wychowania, jest porządkiem miłości. Człowiek bowiem z natury swej dąży do miłości rozumianej jako bezinteresowny dar z siebie samego dla drugiego. Osobę definiuje miłość. Bóg osobowy jest miłością absolutną. Człowiek jako osoba uczy się miłości. Poprzez działanie intelektu poznaje prawdę i dobro i wiąże się aktami woli z rozpoznanym przez siebie dobrem prawdziwym. Człowiek chce kochać i być kochanym, a to realizuje się wówczas, kiedy żyje on prawdą i dobrem, kiedy dostrzega wartość osobową każdego człowieka i w sposób bezinteresowny każdym swym czynem wartość tą afirmuje. Postawa miłości odnosi się zarówno do świata osób, jak i do świata przyrody ożywionej, z którą człowiek pozostaje w sposób szczególny związany przez relacje kontemplacji, symbiozy i pracy ${ }^{1}$. Bezinteresowność, miłość wpisana jest w naturę człowieka. Instytucje społeczne uczestniczące w procesie wychowania winny swoimi działaniami stwarzać takie warunki, aby każdy człowiek - niezależnie od swego wieku - miłość tę mógł w sobie odkrywać, wspomagać ją i ją pielęgnować.

Por., Ks. T. Ślipкo, ks. A. Zwoliński, Rozdroża ekologii, Kraków 1999, ss. 136-139; „....człowiekowi przysługuje prawo i obowiązek traktowania środowiska naturalnego zgodnie $\mathrm{z}$ jego potrójną funkcją w kształtowaniu moralnej doskonałości człowieka jako osoby. Więc winien on szanować przyrodniczy status środowiska naturalnego, chronić go przed dewastacją i używać w granicach wyznaczonych racją rozumnego zharmonizowania przysługujących im uprawnień." Tamże, s. 139. 
Przedstawiając ogólne określenia wychowania zaznaczyliśmy, że wychowanie jest kształtowaniem siebie i realizuje się poprzez przyzwyczajanie się do realizowania dobra. Przyzwyczajenie się do czynienia dobra zgodnie z tradycją filozoficzną nazywamy cnotą. Cnota jest właśnie sprawnością uzdalniającą człowieka do czynienia dobra. Cnota nie jest czymś wrodzonym. Trzeba ją nabyć przez powtarzanie pewnych czynności. Spełnienie dobrego czynu nie czyni człowieka automatycznie dobrym. Może się zdarzyć, że ktoś przez przypadek uczyni coś dobrego, nie oznacza to jeszcze, że jest on dobrym człowiekiem. Ktoś może działać przeżywając nieustannie, w momencie podejmowania decyzji, poważne rozterki, wątpliwości i zmusza się do działania tylko ze względu na opinię zewnętrzną lub ze strachu. Dobrze wychowanym człowiekiem nazwiemy kogoś, kto stale, bez wewnętrznych zmagań i moralnych wahań postępuje dobrze. Możemy nawet przewidzieć jak on się zachowa w pewnych sytuacjach. Jesteśmy gotowi mu zaufać. Człowiek dobrze wychowany posiada wewnętrzną sprawność, skłonność do czynienia dobra, żyje on dobrem. Co nie znaczy że nie mogą mu się zdarzyć akty złego wyboru. Wychowanie ze swej istoty zmierza do świadomego ukształtowania postaw osoby w jej relacji do siebie samej, do świata innych osób, do świata przyrody. Owe postawy mają właśnie charakter moralny i określa się je w etyce mianem cnót. Nauka o cnotach została w obecnych koncepcjach wychowania zapomniana. W Encyklopedii Pedagogicznej (1998) nie znajdziemy hasła „cnota”. Wydaje się, iż warto wrócić do teorii cnót i wykorzystać zawarte w niej bogactwo treści. Nie można utożsamiać cnoty z nawykiem. Nawyk jest bowiem jakimś działaniem automatycznym, nie angażuje on świadomości człowieka, działa niezależnie od woli i ma charakter zmechanizowanej działalności, będącej owocem częstego powtarzania pewnej czynności. Sprawność natomiast nie ma charakteru mechanicznego. Ona wspomaga zdolność świadomego spełniania pewnych czynności. Dzięki sprawności pewne działania są wykonywane szybciej, łatwiej, bez wahań, lecz nie bez udziału rozumu i woli. Sprawności mogą dotyczyć bądź sfery poznawczej, bądź wolitywnej. W pierwszym przypadku mówimy o umiejętnościach teoretycznych, np. wiedza, bądź praktycznych np. rzemiosło. W drugim przypadku, gdy sprawności dotyczą sfery wolitywnej mówimy o cnotach lub wadach moralnych. Relacja człowieka do świata przyrody wypełniona jest wartościami moralnymi i przejawi się w postaci cnót lub wad, jakie podmiot nabył w swoich codziennych relacjach do otaczającego go świata.

\section{Ontyczne podstawy nabywania cnót (wychowania)}

Cnota jest nabytą przez człowieka sprawnością woli umożliwiającą świadome i sprawne działanie człowieka i służy zarazem spełnianiu osobowej struktury podmiotu. Postawa ta ma charakter nabyty oraz tak jak wszystkie cnoty podlega kształtowaniu. To, iż jest ona nabyta nie pomniejsza jej wartości, ponieważ struktura osoby niejako zawiera w sobie miejsce na taką sprawność, jaką jest 
patriotyzm. Sprawność ta jest człowiekowi niezbędnie potrzebna. Odnosi się ona bezpośrednio do struktury osobowego bytu człowieka. Wydaje się, iż w głębszym zrozumieniu związku osoby z rzeczywistością cnót i wychowania pomocą mogą być rozważania filozoficzne kard. Karola Wojtyły i jego koncepcja osoby ${ }^{2}$. W ujęciu Kardynała osoba - zarówno boska jak i ludzka - jest pewną strukturą charakteryzującą się samo - panowaniem, samo - stanowieniem. Osoba jest tym, kto sam siebie posiada i jest jednocześnie posiadana tylko i wyłącznie przez siebie. Jest tym, kto panuje nad sobą (sobie), a jednocześnie tym, nad kim ona panuje ${ }^{3}$. Podmiot i przedmiot panowania i posiadania w osobie utożsamia się. Samoposiadanie i samopanowanie warunkują akt samostanowienia i jednocześnie w nim się ujawniają. Ta wewnętrzna struktura samopanowania i samoposiadania podlega ciągłej aktualizacji w bycie osoby ludzkiej. W bycie absolutnym struktura ta zrealizowana jest w sposób doskonały. Osoba ludzka charakteryzuje się właściwym jej dynamizmem znajduje się ciągle „In fieri.”:

„Człowiek, który raz substancjalnie zaistniał, poprzez wszystko co czyni, a także poprzez wszystko, co w nim się dzieje (...) równocześnie staje się coraz bardziej "jakimś«, a nawet coraz bardziej »kimś «" określone „fieri”. Przede wszystkim jednak człowiek staje się „kimś” poprzez czyn, poprzez świadome działanie, którego jest sprawcą. Autor „Osoby i czynu” rozróżnia dwie płaszczyzny, na których przebiega spełnianie siebie w czynie: płaszczyzna ontologiczna i płaszczyzna aksjologiczna ${ }^{5}$.

Spełnianie siebie na płaszczyźnie ontologicznej polega na aktualizacji wewnątrz-osobowych relacji, na doprowadzeniu do jakiejś pełni tej struktury, która jest właściwa osobie - struktury samopanowania i samoposiadania. Spełnianie to dokonuje się wraz z samostanowieniem. „Spełnianie siebie poprzez czyn, to tyle co urzeczywistnianie samopanowania oraz samoposiadania dzięki samostanowieniu”. W tym spełnianiu siebie człowiek jest „kimś” i jako „ktoś” ciągle się staje. Świadome działanie, w którym człowiek spełnia siebie, stanowi samo w sobie pewną wartość dla człowieka, bo umożliwia mu spełnianie siebie. Wartość tę kard. K. Wojtyła nazywa wartością personalistyczną albo osobową. Jest ona wartością przez to, że czyn jest aktem autentycznego samostanowienia, poprzez które aktualizują się wewnątrz-osobowe relacje. Tkwi ona w samym spełnianiu czynu przez osobę, w samym fakcie, że człowiek działa w sposób sobie włásiwy. Wartość ta „zawiera w sobie cały szereg wartości przynależnych albo do profilu transcendencji, albo integracji, gdyż wszystkie one na swój sposób stanowią

\footnotetext{
Por., H. Niemiec, Kardynała Karola Wojtyly koncepcja osoby, Episteme 2005.

Por. Kard. K. WojtyŁa, Osoba i czyn, Kraków, s. 110.

Osoba i czyn, dz. cyt., s. 101.

Por. tamże, s. 160.

Tamże, s. 159.
} 
o spełnianiu czynu, a równocześnie każda jest wartością dla siebie"7. Wartość personalistyczna czynu jest wyrazem wartości samej osoby jako podmiotu i sprawcy działania. Mimo iż każde spełnienie czynu jest jednocześnie spełnieniem się osoby, to spełnienie to nie ma jednakowej wartości dla tejże osoby ${ }^{8}$. Na gruncie wartości personalistycznej „zakorzenia się”, ale się z nią nie utożsamia, moralna wartość czynu spełnianego, wynikająca z odniesienia do normy. Człowiek spełnia siebie jako osoba i jako osoba, jako ktoś, może się stawać dobry lub zły. Stawanie się dobrym lub złym, uzależnia kard. K. Wojtyła od wartości moralnej, którą człowiek urzeczywistnia w spełnianym czynie. Człowiek podejmując konkretne świadome działanie - czyn, działa w zgodności lub niezgodności z normą. Spełniony czyn jest dobry lub zły moralnie i sam człowiek jako osoba staje się dobry lub zły. Zaangażowanie osoby w działaniu uprzedmiotawia się nie tylko w zewnętrznym wytworze działania, ale uprzedmiotawia się - ze względu na nieprzechodni charakter czynu - w samej osobie. Przez czyn moralnie dobry sam człowiek jako osoba - sprawca czynu - staje się moralnie dobry. Przez czyn moralnie zły człowiek staje się moralnie zły. Wartość moralna czynu uwarunkowana jest - w ujęciu kard. K. Wojtyły - wartością personalistyczną czynu (czyn jest aktem osoby i ma charakter prawdziwego samostanowienia aktualizującego wewnątrz - osobowe relacje). Jeżeli czyn wykazuje braki w zakresie autentycznego samostanowienia „....wówczas i wartość moralna traci w nim niejako grunt pod nogami, przynajmniej do pewnego stopnia"9. Wartości moralne mogą istnieć tylko i wyłącznie na gruncie wartości osobowych ${ }^{10}$. Kardynał K. Wojtyła, ujmując wartość moralną na gruncie bytu ludzkiego i jego stawania się - „fieri”, odcina się tym samym od interpretacji fenomenologicznej, według której wartość jest tylko zapodmiotowiona w człowieku. Moralność i wartości moralne zostają w niej ograniczone tylko do wymiaru zjawiskowego, do pewnych treści świadomości. W ujęciu kard. K. Wojtyły wartość moralna nie jest tylko zapodmiotowana w człowieku. Ona przenika byt osobowy człowieka ${ }^{11}$. Zespala się z nim i sprawia, że sam podmiot staje się dobry lub zły, przyjmując wartość moralną spełnianego działania. Tomizm, podkreślając realność wartości moralnych i działania moralnego, utożsamia, w pewnym stopniu, każde spełnienie się człowieka $\mathrm{z}$ wartością moralną. Fenomenologia natomiast, ukazując swoistość wartości moralnych i ich odrębność od wartości personalistycznych, odrywa wartość moralną od realnego spełnienia się człowieka. Kard. K. Wojtyła rozważając wartość personalistyczną i wartość moralną oraz ujmując tę ostatnią na

\footnotetext{
Tamże, s. 288.

Por. J. W. GaŁkowski, Sumienie a transcendencja, RF 28:1980, z. 2, s. 144.

Osoba i czyn, dz. cyt., s. 290.

Por. J. W. GA£KowsKi, Praca i człowiek, Warszawa 1980, s. 212-214.

11 Por. Kard. K. WojtyŁa, Problem teorii moralności, w: W nurcie zagadnień posoborowych. T. 3, Warszawa 1969, s. 232.
} 
gruncie bytu i jego „stawania się”, „znajduje się między” filozofią bytu a filozofią świadomości ${ }^{12}$. Jego zdaniem dobro i zło moralne przenika do porządku ontologicznego. W głębi człowieka dochodzi do zjednoczenia płaszczyzny aksjologicznej z ontologiczną ${ }^{13}$. Rzeczywistość aksjologiczna, której wyrazem są wartości moralne, zakorzenia się w rzeczywistości ontologicznej. Związek między nimi jest tak ścisły, że - zdaniem kard. K. Wojtyły - właściwe osobie spełnianie siebie dokonuje się dopiero na płaszczyźnie aksjologicznej. „Wartości moralne bowiem są tak istotne dla osoby, że prawdziwe jej spełnianie dokonuje się nie tyle przez sam czyn, ile przez moralną dobroć tego czynu. Zło zaś moralne stanowi raczej o niespełnieniu, chociaż osoba również wówczas spełnia czyn"14. W niespełnieniu siebie jest coś z nieistnienia, nie - urzeczywistnienia tego, co mogło i powinno się stać rzeczywistością. Właściwe spełnianie siebie dokonuje się tylko poprzez dobroć czynu. Moralność jako rzeczywistość aksjologiczna, rozszczepiająca się na dobro lub zło jest, w rozumieniu kard. K. Wojtyły, rzeczywistością egzystencjalnie związaną z osobą. Poprzez wartość moralną, moralność uzyskuje wewnątrz człowieka swoją realność i konkretność jako owoc sprawczości, samostanowienia oraz odniesienia do normy moralności ${ }^{15}$.

\section{Spełnianie się osoby a idea zrównoważonego rozwoju}

U podstaw etyki ekologicznej znajduje się wizja człowieka - ludzkiej osoby, która poprzez praktykę codziennego działania realizuje tkwiące w niej osobowe potencjalności, dążąc do właściwej sobie doskonałości. Rozwój osoby - In fieri - ma charakter moralny. Płaszczyzna aksjologiczna przenika płaszczyznę ontologiczną, nadając jej nową jakość. Poprzez czyn moralnie dobry sam człowiek, sprawca czynu, otrzymuje nową realną jakość, realizuje tkwiące w nim doskonałości, rozwija pozytywnie swe człowieczeństwo.

W orbitę moralnych działań wchodzi otaczający osobę świat przyrody ożywionej i nieożywionej, uczestnicząc w osobowym doskonaleniu się człowieka. Relacja

12 Por. tamże, s. 248.

136 XII 1979 roku odbyło się w Bibliotece Uniwersyteckiej KUL sympozjum na temat: „Człowiek w świetle sumienia - w kontekście filozoficzno-teologicznej twórczości kard. K. Wojtyły”. Referaty wygłoszone na sympozjum oraz treść dyskusji zostały opublikowane w RF 28:1980, z. 2, s. 103175. Umieszczone poniżej oznaczenia stron odnoszą się do tego numeru Roczników. Problem spełniania się osoby na płaszczyźnie ontologicznej i aksjologicznej poruszony były w referatach: A. WaWrzyniaka, Bytowo-osobowy wymiar sumienia, s. 125-138; A. RodzińsKiego, Na prawach „głośnego myślenia", s. 139; J. W. GA£KOWsKIEGo, Sumienie a transcendencja, s. 145; T. STYCZNIA, Ja wświetle swego sądu: powinienem..., s. 153.

14 Osoba i czyn, dz. cyt., s. 160-161.

15 „Moralność jest rzeczywistością, która wchodzi w rzeczywistość ludzkich czynów jako swoiste »fieri« podmiotu - »fieri« najgłębsze, najistotniej związane zarówno z jego naturą, czyli człowieczeństwem, jak też z faktem, że jest osobą". Osoba i czyn, dz. cyt., s. 104. 
jaka zachodzi między człowiekiem a światem przyrody winna być przeniknięta kategorią dobra wspólnego. Dobrem wspólnym jest takie dobro, którego istnienie umożliwia realizację tkwiących w człowieku osobowych potencjalności. Dobrem wspólnym jest rozwój osoby (oczywiście jest nim również sama osoba ludzka), ale dobrem wspólnym jest również świat przyrody i jego istnienie oraz jakość jego istnienia. Jakość świata przyrody ma wpływ na proces doskonalenia osobowego człowieka. Człowiek bowiem z jednej strony jest częścią przyrody, z drugiej zaś potrzebuje przyrody dla swego osobowego rozwoju. Musi więc troszczyć się o zachowanie równowagi w relacji, tak do świata osób, jak i świata przyrody. Nie zawsze jednak konkretny człowiek w sposób właściwy rozpoznaje wartość świata przyrody oraz potrzebę troski o zrównoważony rozwój. Bardzo często spotykamy się z niezawinioną niewiedzą $\mathrm{w}$ tej materii, dlatego konieczne są działania edukacyjne, które pomogą dojrzeć tę wartość i skutecznie zachęcą do budowania odpowiedzialnych proekologicznych postaw (cnót). Cnota usprawnia wolę człowieka do działań moralnie dobrych. Proces nabywania cnót zawsze poprzedzony jest odpowiednim rozpoznaniem prawdy o dobru zawartym w działaniu, które ma nastąpić. Trzeba wpierw poznać dobro, aby móc go pragnąć. Oczywiście sama wiedza nie zastępuje moralności. Nie wystarczy bowiem wiedzieć czym jest cnota, aby być cnotliwym człowiekiem. Niemniej wiedza jest konieczna, aby mógł zaistnieć świadomy proces kształtowania moralnego, jest ona warunkiem cnoty oraz sprawia, że człowiek działa świadomie i rozumnie i może uzasadnić swoje postępowanie. Człowiek posiadający odpowiednią wiedzę jest w stanie skłonić samego siebie do podjęcia działań, które mogą być niepopularne, które wymagają od niego wysiłku, a nawet poświęcenia $\mathrm{z}$ jego strony, lecz ponieważ prowadzą one do dobra, to człowiek świadomie jest gotów ponieść ów trud. W procesie wychowania nie można bagatelizować formacji intelektualnej. Właściwe rozpoznanie prawdy i dobra daje siłę do ich urzeczywistniania codzienną praktyką życia.

W życiu społecznym podstawowym edukatorem odpowiedzialnym za tworzenie klimatu sprzyjającemu tworzeniu proekologicznych postaw jest władza państwowa na różnych szczeblach jej reprezentacji, taki sam obowiązek spoczywa na szkole, rodzinie oraz społecznościach kościelnych. Świat przyrody jest wspólnym dobrem wszystkich ludzi i każdego człowieka, dlatego odpowiedzialność za jego jakość rozkłada się na wszystkie naturalne grupy społeczne. Rozwój przemysłu i związane z nim zagrożenia zmuszają do większej odpowiedzialności za wszelkie wytwory pracy ludzkiej. Wszystkie formy życia społecznego muszą wspólnie uczestniczyć w budowaniu społeczeństwa odpowiedzialnego za kształt środowiska, w którym rozwija się osobowe życie członków owej społeczności.

Władza państwowa poprzez odpowiednie ustawodawstwo oraz poprzez konsekwencje jego przestrzegania, może ukazywać wartość przyrody oraz to, jaką pełni ona rolę w życiu osobowym i społecznym człowieka. Społeczeństwo polskie niestety nie docenia jeszcze tej wartości. Potrzeba odpowiednich działań, aby 
każdy obywatel przekonał się do wszelkich działań pro - ekologicznych. Chodzi nie tylko o wielkie programy, mające na celu ochronę środowiska, lecz o prozaiczne sprawy, z którymi obywatel codziennie się styka, tj. takie jak na przykład: segregacja odpadów, oszczędzanie energii elektrycznej. Odpowiednia polityka finansowa ( np. ulgi podatkowe) winna sprzyjać wszelkim inicjatywom mającym na celu zmniejszanie zanieczyszczeń, zwiększanie źródeł energii odnawialnej, energooszczędne budownictwo. Odpowiednia reklama działań proekologicznych w środkach masowego przekazu sprzyja budzeniu właściwych postaw. Obywatel winien również dostrzegać autentyczną troskę samorządu lokalnego o czystość środowiska naturalnego człowieka.

Ogromne znaczenie w kształtowaniu proekologicznej świadomości należy przypisać szkolnictwu na wszystkich szczeblach edukacji. Cele ekologiczne może ona realizować na dwóch płaszczyznach.

Pierwsza płaszczyzna to dziedzina związana bezpośrednio z nauczaniem. Poprzez nauczanie biologii, geografii, a nawet literatury można ukazywać piękno przyrody oraz jej wartość dla życia człowieka i w ten sposób kształtować postawy proekologiczne. W ramach każdego przedmiotu istnieje przestrzeń na kształtowanie postaw sprzyjających właściwemu ustalaniu relacji człowiek - przyroda. Wydaje się, iż nie ma potrzeby wprowadzania odrębnego przedmiotu nauczania dotyczącego problemów z zakresu ochrony środowiska naturalnego. Nie można tej problematyki ideologizować, zamykać w ścisłych ramach jednego tylko przedmiotu. Winna się ona pojawiać systematycznie w krzyżujących się zajęciach różnych dyscyplin na różnym etapie kształcenia.

Druga płaszczyzna, na której należy kształtować postawy proekologiczne to przykład, jaki daje szkoła oraz nauczyciele w zakresie ochrony środowiska naturalnego. Uczeń musi naocznie doświadczyć tego, jak szkoła troszczy się o środowisko. Musi on się przekonać, że treści te nie mają czysto teoretycznego charakteru, lecz mają wymiar praktyczny obecny w konkretnych działaniach szkoły. Przykład szkoły odgrywa ogromną rolę. Może on przybierać różne formy: od troski o czystość i oszczędzanie energii, aż po przykład własnych odnawialnych źródeł energii.

Przykład szkoły winien być przeniesiony na atmosferę rodzinnego domu. Nikt lepiej nie nauczy dzieci wartości środowiska. Rodzice przy współpracy ze szkołą, przykładem własnego postępowania mogą nauczyć dzieci tego, jak należy się troszczyć o osobisty rozwój w harmonijnej trosce o naturalne środowisko. Środowisko domu stwarza szereg okazji do wykazania się troską o czystość tegoż środowiska. Prozaiczne zagadnienia takie jak: segregacja odpadów, spalanie odpadów w piecach CO, wykorzystanie wód deszczowych, troska o okoliczne lasy, są doskonałą lekcją dla młodego pokolenia. Młodzież potrzebuje autentycznego świadectwa troski o naturalne środowisko, w którym żyjemy. 
Organizacje kościelne są ważnym autorytetem wzmacniającym wszelkie działania proekologiczne. W ramach religii chrześcijańskiej znajdujemy najgłębszą argumentację za działaniami proekologicznymi. Świat stworzony jest przez Boga i posiada swą wewnętrzną wartość związaną z osobowym spełnieniem się człowieka w sieci relacji osobowych, powiązanych z relacjami do świata przyrody. Istnieje potrzeba programu duszpasterskiego, który w oparciu o cnotę sprawiedliwości ukaże wierzącym naturalną potrzebę troski o środowisko naturalne, w którym żyjemy. Brak owej troski winien być jednoznacznie potraktowany jako grzech. Wydaje się, iż w naszym społeczeństwie brak jest świadomości grzeszności działań szkodzących - świadomie bądź nieświadomie - środowisku.

Warto również zwrócić uwagę na sposób budowania świadomości proekologicznej. Najczęściej spotykanym sposobem jest argumentacja o charakterze negatywnym . Ukazuje się w jej ramach negatywne skutki związane z brakiem troski o naturalne środowisko człowieka, takie jak: zmiany klimatyczne, efekt cieplarniany i jego skutki, zanikanie tradycyjnych pór roku, szkodliwy wpływ roślin modyfikowanych genetycznie. Niewątpliwie tezy te są prawdziwe. Jednakże względy pedagogiczne skłaniają nas do wskazywania na wartość przyrody jako wartość samą w sobie, godną miłowania dla niej samej, jako wartość, która służy osobowemu spełnieniu się człowieka. Świat przyrody sam w sobie jest piękny i może być przedmiotem kontemplacji. Piękno to uczestniczy w rozwoju duchowych aktywności człowieka. Pozytywne aspekty działań proekologicznych posiadają większą siłę perswazyjną i motywującą zarazem. Uwagi te dotyczą zarówno oddziaływania na świat ludzi młodych jak i dorosłych.

Działania edukacyjne winny sprzyjać budowaniu postaw, które będą przyjazne środowisku naturalnemu. Postawy te są realną jakością obecną w osobie w postaci cnót uzdalniających osobę do działań moralnie dobrych. Nie ma odrębnej „cnoty ochrony środowiska”. Wszelkie działania proekologiczne będą związane z kardynalnymi cnotami roztropności i sprawiedliwości oraz ze związanymi z nimi cnotami np.: cnotą rozwagi, umiejętnością przewidywania, przezorności, szacunku, wdzięczności. Cnota roztropności - woźnica cnót - uzdalnia człowieka do zachowania umiaru w podejmowaniu decyzji. W sporach o charakterze ekologicznym zawsze spotykamy się z konfliktami wartości, aby uniknąć skrajności, potrzebna jest roztropność, mająca na uwadze dobro wspólne. Właściwie problematyka etyczna znajduje się u podstaw wszelkich działań pro-ekologicznych. Rozwój cywilizacji rodzi bowiem szereg problemów związanych z kierunkiem i sposobami tegoż rozwoju. Powstaje pytanie czy wszelki rozwój jest uzasadniony?, jakie są jego granice? Z pewnością cywilizacja, która występuje przeciw życiu i godności człowieka nie zasługuje na miano właściwej ludzkiej cywilizacji. Etyka winna poprzedzać rozwój techniki i wpływać na kierunki tegoż rozwoju. Cnota roztropności umożliwia zachowanie odpowiednich proporcji. Klasycznym przykładem jest roztropne budowanie dróg, nawet kosztem lasów, 
aby umożliwić budowę ciągów komunikacyjnych i rozwój cywilizacji. Oczywiście rozwój prawdziwy cywilizacji będzie miał na uwadze poszanowanie przyrody, zachowanie równowagi między rozwojem osobowym człowieka, rozwojem cywilizacji, a stanem jakości środowiska naturalnego. Najważniejszy jest rozwój osobowych potencjalności człowieka, który możliwy jest tylko w działaniach zachowujących naturalną wartość środowiska.

Cnota roztropności wiąże się w tym punkcie analiz z cnotą sprawiedliwości. Cnota sprawiedliwości nakazuje oddać każdemu to, co mu się należy. Można powiedzieć, iż człowiekowi, który jest jednością duchowocielesną, należy się odpowiednia jakość środowiska w którym żyje, ponieważ ma ona wpływ na rozwój zarówno sfery duchowej, jak i cielesnej. Sprawiedliwość nakazuje w sposób odpowiedzialny myśleć o tych, którzy będą żyli na ziemi za 50, 100 lat. Nie można przyszłym pokoleniom zostawić zdegradowanego środowiska. Z drugiej strony przyroda posiada swą wewnętrzną wartość, piękno skłaniające do kontemplacji. Sprawiedliwość domaga się, aby to piękno trwało. Działania edukacyjne winny ukazywać owo piękno i kształtować postawę szacunku wobec środowiska naturalnego.

Idea wychowania do zrównoważonego rozwoju dotyka u swych podstaw realnego rozwoju człowieka, jego dążenia do osobowej doskonałości. Owocem wychowania ma być odpowiednie ukształtowanie wolitywno - intelektualnej władzy człowieka, która umożliwi poprzez akty konkretnych decyzji realizację osoby, jej doskonałość. Świat przyrody wchodzi w orbitę moralnych działań ludzkiej osoby. Rozwój będzie miał właściwy charakter tylko wtedy, gdy cywilizacja, będąca dziełem człowieka nie będzie zagrażała istnieniu i godności osobowego bytu ludzkiego. Podstawowym warunkiem właściwego rozwoju cywilizacji jest zachowanie odpowiedniej jakości środowiska naturalnego. Cnoty sprawiedliwości i roztropności umożliwiają kierowanie się kategorią dobra wspólnego przy podejmowaniu decyzji, co z kolei umożliwia zrównoważony rozwój człowieka i jego wytworów. 